\title{
Transfer of ${ }^{137} \mathrm{Cs}$ and ${ }^{90} \mathrm{Sr}$ from finnish soils to cereal grains
}

\author{
E. Kostiainen and A. Rantavaara \\ STUK, Radiation and Nuclear Safety Authority, Research and Environmental Surveillance, \\ P.O. Box 14, 00881 Helsinki, Finland
}

\begin{abstract}
The transfer of ${ }^{137} \mathrm{Cs}$ and ${ }^{90} \mathrm{Sr}$ from soil to cereal grains in various regions in Finland was studied in $1994-$ 1997. The samples of cereal grains were collected from private farms and combined to represent different soil types and regions in Finland. Altogether 318 composite regional samples of rye, wheat, oats and barley were analysed for ${ }^{137} \mathrm{Cs}$, and 45 for ${ }^{90} \mathrm{Sr}$. The aggregated transfer factors from the mean regional ${ }^{137} \mathrm{Cs}$ deposition $\left(\mathrm{kBa}^{-2}\right)$ to cereal grains were calculated. The soils were classified in three main types; organic, sand and silt, and clay soils. The mean transfer factors $\left(\mathrm{m}^{2} \mathrm{~kg}^{-1}(\mathrm{dw})^{*} 10^{-3}\right)$ of ${ }^{137} \mathrm{Cs}$ for cereal grains were highest in organic soils ranging from 0.013 to 0.12 , lowest in clay soils, ranging from 0.015 to 0.061 , and decreased in the order: oats $>$ rye $>$ barley on wheat. The concentrations of ${ }^{90} \mathrm{Sr}$ were higher in the cereal grains from sand and silt soils than from the clay and organic soils. The regional ${ }^{137} \mathrm{Cs}$ transfer factors from soil to cereal grains found in this study were compared with data for the nuclear weapons fallout period and for a few post-Chernobyl years.
\end{abstract}

\section{INTRODUCTION}

The transfer of ${ }^{137} \mathrm{Cs}$ and ${ }^{90} \mathrm{Sr}$ to cereal grains in various regions in Finland was monitored in 1994-1997. The contents of radiocaesium and radiostrontium in cereals have been monitored since 1962 yearly in Finland by composite samples from major production areas [1-8]. In 1994 - 1995 sampling was intensified by taking samples in addition to the regional samples from private farms with information on the soil types of the fields. The transfer of ${ }^{137} \mathrm{Cs}$, accumulated in soil $\left(\mathrm{kBq} \mathrm{m}^{-2}\right)$ regionally, to rye, wheat, oats and barley was estimated for samples from organic, sand and silt, and clay soils. For comparison, data for regiona] surveillance samples were used, classified to correspond to the farm-specific data.

Soil types in Finland are different in eastern, western and northem production areas. The aim of the study was to find regional differences in the transfer of radionuclides. The information on ${ }^{137} \mathrm{Cs}$ deposited in the production areas was based on monitoring deposited material in the period 1960 - spring 1986, and the mobile survey of environmental gamma radiation and fallout levels in Finland after the Chemobyl accident $[9]$.

\section{MATERIAL AND METHODS}

\subsection{Sampling and sample treatment}

Our study was based on the samples collected originally by Grain Laboratory in the Plant Production Inspection Centre nation-wide from private farms, altogether 1400 samples. The farmers gave the information on the associated soil types of the fields. The samples of wheat, rye, oats and barley were taken in 1994-1995, and in addition rye samples in 1996-1997 to improve the representativeness of various soil types and production areas. The soil types given by farmers were: sand, fines and, silt, sandy clay, silty clay, clay, humus, mud and peat soils. The samples from private farms were combined according to given soil types and categories of ${ }^{137} \mathrm{Cs}$ deposition (Figure 1) of the sampling region by taking equal amounts of undried samples to form composite samples (Table 1). 


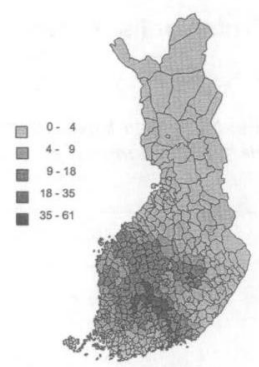

Figure 1. Chemobyl ${ }^{137} \mathrm{Cs}$ deposition in Finland on $1^{\text {si }}$ October 1998, $\mathrm{kBq} \mathrm{m}{ }^{-2}[9]$.

Table 1. Number of grain samples for soil types (sub samples and analysed composite samples) in 1994-1997. The three soil type categories are given.

\begin{tabular}{|c|c|c|c|c|c|c|c|c|}
\hline \multirow[b]{2}{*}{ Soil type } & \multicolumn{2}{|l|}{ Rye } & \multicolumn{2}{|l|}{ Wheat } & \multicolumn{2}{|l|}{ Oats } & \multicolumn{2}{|l|}{ Barley } \\
\hline & $\begin{array}{l}\text { Sub- } \\
\text { samples }\end{array}$ & $\begin{array}{l}\text { Composite } \\
\text { samples }\end{array}$ & $\begin{array}{l}\text { Sub- } \\
\text { samples }\end{array}$ & $\begin{array}{l}\text { Composite } \\
\text { samples }\end{array}$ & $\begin{array}{l}\text { Sub- } \\
\text { samples }\end{array}$ & $\begin{array}{l}\text { Composite } \\
\text { samples }\end{array}$ & $\begin{array}{l}\text { Sub- } \\
\text { samples }\end{array}$ & $\begin{array}{l}\text { Composite } \\
\text { samples }\end{array}$ \\
\hline \multicolumn{9}{|l|}{ Sand and silt } \\
\hline sand & 23 & 17 & 2 & 1 & 8 & 6 & 4 & 2 \\
\hline fine sand & 14 & 9 & 6 & 2 & 57 & 12 & 54 & 10 \\
\hline silt & 28 & 14 & 4 & 3 & 23 & 6 & 34 & 8 \\
\hline \multicolumn{9}{|l|}{ Clay } \\
\hline sandy clay & 16 & 6 & 35 & 4 & 47 & 9 & 77 & 10 \\
\hline silty clay & 68 & 24 & 47 & 5 & 74 & 12 & 151 & 16 \\
\hline clay & 51 & 22 & 81 & 5 & 89 & 12 & 143 & 13 \\
\hline \multicolumn{9}{|l|}{ Organic } \\
\hline humus & 8 & 7 & 11 & 4 & 69 & 12 & 48 & 10 \\
\hline mud & 12 & 8 & - & - & 52 & 16 & 33 & 11 \\
\hline peat & 5 & 4 & 1 & 1 & 18 & 9 & 10 & 8 \\
\hline
\end{tabular}

In addition to the samples from farms with known soil type, 1600 surveillance samples of cereal grains with information on the sampling municipality were collected in the main agricultural production area in western and southwestern Finland in 1994-1995. These samples were combined according to the ${ }^{137} \mathrm{Cs}$ deposition and the predominant field soil type of the municipality [10] grouped in three categories (Table 2).

Table 2. Number of surveillance samples (sub samples and analysed composite samples) in $1994-1995$.

\begin{tabular}{|c|c|c|c|c|c|c|c|c|}
\hline \multirow[b]{2}{*}{ Soil type } & \multicolumn{2}{|l|}{ Rye } & \multicolumn{2}{|l|}{ Wheat } & \multicolumn{2}{|l|}{ Oats } & \multicolumn{2}{|l|}{ Barley } \\
\hline & $\begin{array}{l}\text { Sub- } \\
\text { samples }\end{array}$ & \begin{tabular}{|l} 
Composite \\
samples
\end{tabular} & $\begin{array}{l}\text { Sub- } \\
\text { samples }\end{array}$ & \begin{tabular}{|l}
$\begin{array}{l}\text { Composite } \\
\text { samples }\end{array}$ \\
\end{tabular} & $\begin{array}{l}\text { Sub- } \\
\text { samples }\end{array}$ & \begin{tabular}{|l} 
Composite \\
samples
\end{tabular} & $\begin{array}{l}\begin{array}{l}\text { Sub- } \\
\text { samples }\end{array} \\
\end{array}$ & $\begin{array}{l}\text { Composite } \\
\text { samples }\end{array}$ \\
\hline Organic & - & $=$ & - & - & 2 & 1 & - & $=$ \\
\hline Clay & 70 & 10 & 646 & 41 & 138 & 17 & 262 & 25 \\
\hline Sand & 23 & 17 & 2 & 1 & 8 & 6 & 4 & 2 \\
\hline
\end{tabular}

The composite samples were dried in an oven at $105^{\circ} \mathrm{C}$ for the determination of the dry matter contents, and ashed at $400^{\circ} \mathrm{C}$ before analysing of ${ }^{137} \mathrm{Cs}$ and ${ }^{90} \mathrm{Sr}$. 


\subsection{Sample analysis}

\subsection{Gamma-spectrometric analyses}

The ashed composite samples were analysed for ${ }^{137} \mathrm{Cs}$ with low-background high-resolution gamma spectrometers in cylindrical beakers with a volume of $0.03 \mathrm{dm}^{3}$ and a $42 \mathrm{~mm}$ diameter on top of the detector. The germanium detectors are placed in cylindrical background shields, the $12-14 \mathrm{~cm}$ thick lead walls of which are covered inside with cadmium $(1 \mathrm{~mm})$ and copper $(0.5 \mathrm{~mm})$ to reduce the effect of $x$-rays. The measuring times were 16 hours. The activity concentrations of the samples were calculated using the GAMMA-83 computer code developed at STUK [11-12].

\subsubsection{Determination of radiostrontium}

For radiostrontium, determination the ashed samples were dissolved in hydrochloric acid. The insoluble residue was dissolved using a sodium carbonate fuse and added to the acid solution.

Two methods were used to separate radiostrontium with Sr-carrier. One method was a slightly modified method [13], applied at STUK for vegetation samples where the separation is based on successive precipitations. The essential steps separating strontium from calcium were nitrate precipitations with fuming nitric acid. The other method was an extraction chromatographic method [14], modified for vegetation samples, where Eichrom resin was used to separate strontium. After separating strontium it was precipitated as carbonate. The precipitate was dissolved in $\mathbf{H C l}$, and the sample divided into fractions used for yield determination with AAS and measurement of ${ }^{90} \mathrm{Sr}$ activity with a low-background liquid scintillation spectrometer.

\subsection{Data treatment}

The transfer coefficient $\left(\mathrm{Bq} \mathrm{kg}{ }^{-1} \mathrm{dw} / \mathrm{kBq} \mathrm{m}^{-2}\right.$ ) from mean regional ${ }^{137} \mathrm{Cs}$ deposition $\left(\mathrm{kBq} \mathrm{m}^{-2}\right)$ to cereal grains was calculated for 229 composite samples. For analysing the transfer ratio data were grouped according to the soil types of the samples into three categories: clay, sand and silt, and organic soils. Sand, fine sand and silt were included in sandy soils, sandy clay, silty clay and clay in clay soils, and humus, mud and peat in organic soils. The medians and upper and lower quartiles of the transfer ratios were determined for rye, wheat, oats and barley in clay, sand and silt, and organic soils.

Transfer ratios were calculated also for the surveillance data of cereal grains from the years 19801995. The transfer ratio data from this study and from surveillance programs were grouped in three soil type. The area of Finland was divided in three regions according to predominant soil types of cultivated fields: clay, sand and silt, and organic (Figure 2). The characteristics of the fields of these regions are given in Table 3.

Table 3. Characteristics of Finnish cultivated soils in 1994-1995 devised in three categories according to predominant soil type of the region.

\begin{tabular}{|l|l|l|l|l|}
\hline Area & $\begin{array}{l}\text { Predominating soil } \\
\text { type }\end{array}$ & $\mathrm{pH}$ & $\begin{array}{l}\mathrm{Ca} \\
\mathrm{mg} / 1\end{array}$ & $\begin{array}{l}\mathrm{K} \\
\mathrm{mg} / 1\end{array}$ \\
\hline $\begin{array}{l}\text { Southem and south- } \\
\text { westem coast (1) }\end{array}$ & $\begin{array}{l}\text { clay } \\
(40-70 \%)\end{array}$ & $>5.9$ & $>2100$ & $150-220$ \\
\hline Central and eastern (2) & $\begin{array}{l}\text { sand } \\
(>80 \%, \text { clay }<5 \%)\end{array}$ & $5.8-5.9$ & $1300-1700$ & $110-150$ \\
\hline Northern (3) & $\begin{array}{l}\text { organ } \\
(>30 \%)\end{array}$ & $<5.8$ & $1300-1400$ & $104-135$ \\
\hline
\end{tabular}




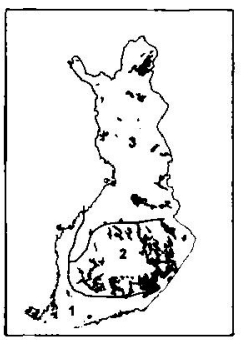

Figure 2. Division of Finland in three regions according to predominant types of cultivated soils

\section{RESULTS AND DISCUSSION}

The transfer ratios of ${ }^{137} \mathrm{Cs}$ from soil to cereal grains were highest in organic soils for oats, rye and barley, and lowest in clay soils (Table 4). The uptake of ${ }^{137} \mathrm{Cs}$ decreased in the samples from the same sampling areas in the order: oats $>$ rye $>$ barley, wheat. The transfer ratios of rye and oats showed greater variation than those of barley and wheat. This may reflect greater variability in growing conditions of rye and oats.

Table 4. Transfer ratios of ${ }^{137} \mathrm{Cs}$ from deposit to cereal grains $\left(\mathrm{Bq} \mathrm{kg}^{-3} \mathrm{dw} / \mathrm{kBq} \mathrm{m}^{-2}\right)$. Median and range $=$ difference between the upper and lower quartiles, $\mathrm{N}=$ number of analysed samples.

\begin{tabular}{|l|l|l|l|}
\hline & Clay & Sand and silt & Organic \\
\hline Barley & $0.018 ; 0.014-0.025(\mathrm{~N}=37)$ & $0.028 ; 0.015-0.070(\mathrm{~N}=18)$ & $0.040 ; 0.024-0.063(\mathrm{~N}=28)$ \\
\hline Oats & $0.061 ; 0.038-0.093(\mathrm{~N}=33)$ & $0.10 ; 0.067-0.15 \quad(\mathrm{~N}=23)$ & $0.12 ; 0.068-0.41(\mathrm{~N}=37)$ \\
\hline Rye & $0.015 ; 0.009-0.020(\mathrm{~N}=46)$ & $0.028 ; 0.015-0.046(\mathrm{~N}=37)$ & $0.072 ; 0.045-0.20(\mathrm{~N}=19)$ \\
\hline Wheat & $0.015 ; 0.013-0.020(\mathrm{~N}=11)$ & $0.031 ; 0.023-0.068(\mathrm{~N}=6)$ & $0.013 ; 0.011-0.016(\mathrm{~N}=5)$ \\
\hline
\end{tabular}

The data of transfer ratios for the surveillance data in 1994-1995 showed reasonably well the same pattern obtained for the data with known soil types (Figure 3). The data of transfer ratios of ${ }^{137} \mathrm{Cs}$ from deposit to cereal grains (Bq kg ${ }^{-1} \mathrm{dw} / \mathrm{kBq} \mathrm{m}^{-2}$ ) representing three regions: 1 (clay), 2 (sand and silt) and 3 (organic) are given in Figure 4, include both the surveillance data [2-8] (1980-1995), and the results of this study (1994-1997).
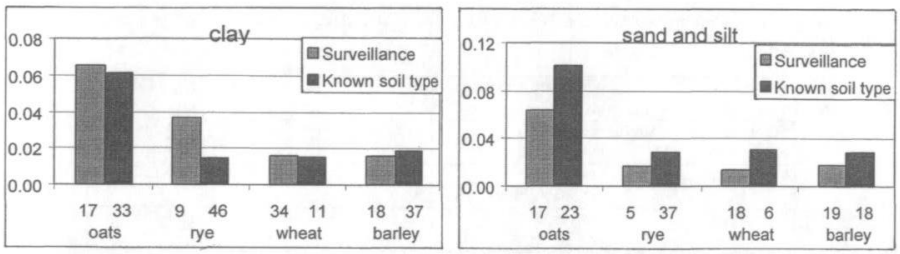

Figure 3. The medians of transfer ratios of the surveillance data and the data with known soil type $\left(\mathrm{Bq} \mathrm{kg}{ }^{-1} / \mathrm{kBq}_{\mathrm{ma}}^{-2}\right)$. Number of analysed samples is given. 

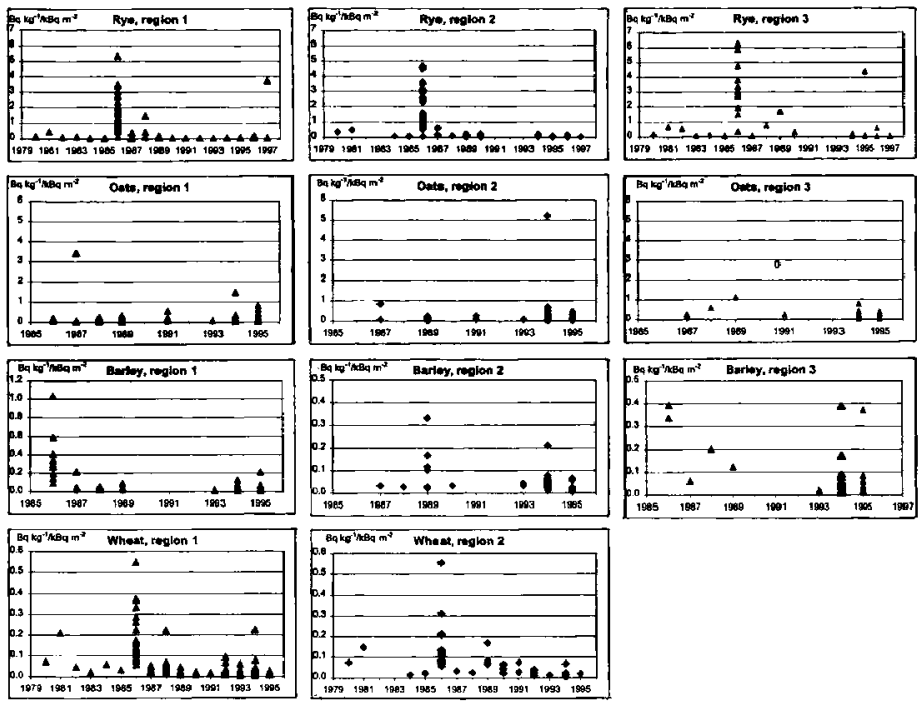

Figure 4. Transfer ratios of ${ }^{137} \mathrm{Cs}$ from deposit to cereal grains $\left(\mathrm{Bq} \mathrm{kg}^{-1} \mathrm{dw} / \mathrm{kBq} \mathrm{m}^{-2}\right)$. Combined surveillance data from $1980-$ 1995, and the farm-specific results of this study (1994-1997).

The concentrations of ${ }^{90} \mathrm{Sr}$ were higher in the cereal grains from sand and silt soils than from the clay and organic soils, and decreased by cereal type in the order: oats $>$ barley $>$ rye $>$ wheat in all soils from the same sampling regions (Table 5). The variation in ${ }^{90} \mathrm{Sr}$ concentrations includes also the regional variation of ${ }^{90} \mathrm{Sr}$ deposition in. Finland. The ${ }^{90} \mathrm{Sr}$ results of this study were consistent with the findings of Paasikallio et al [15-18], which showed that increasing organic matter content and increasing clay content decreased the uptake of radiostrontium by plants. The ${ }^{90} \mathrm{Sr}$ concentrations in cereal grains were lower in the regions of increasing soil $\mathrm{pH}$ and increasing content of exchangeable Ca. The ratio ${ }^{90} \mathrm{Sr} /{ }^{137} \mathrm{Cs}$ was higher in samples from clay and sand soils than from organic soils in same areas reflecting the caesium-binding capacity of clay soils [15-18].

Table 5. ${ }^{90} \mathrm{Sr} \mathrm{Bq} \mathrm{kg}{ }^{-1}$ in Finnish cereal grains in 1994-1995, median and range (number of samples given in parenthesis).

\begin{tabular}{|l|l|l|l|}
\hline & Clay & Sand and silt & Organic \\
\hline Barley & $0.31,0.33(\mathrm{~N}=2)$ & $0.40,0.55(\mathrm{~N}=2)$ & $0.29,0.63(\mathrm{~N}=2)$ \\
\hline Oats & $0.42 ; 0.25-0.61(\mathrm{~N}-6)$ & $0.49 ; 0.28-1.6(\mathrm{~N}=5)$ & $0.39 ; 0.23-0.47(\mathrm{~N}=6)$ \\
\hline Rye & $0.19 ; 0.12-0.30(\mathrm{~N}=4)$ & $0.41,0.42(\mathrm{~N}=2)$ & $0.19 ; 0.11-0.25(\mathrm{~N}=3)$ \\
\hline Wheat & $0.14 ; 0.11-0.76(\mathrm{~N}=4)$ & $0.32,0,53(\mathrm{~N}=2)$ & $0.08 ; 0.039-0.085(\mathrm{~N}=3)$ \\
\hline
\end{tabular}

This study resulted in distributions of transfer parameters for ${ }^{137} \mathrm{Cs}$, which represent real production conditions. The regional surveillance data gives reasonably well the ${ }^{137} \mathrm{Cs}$ concentration levels when sitespecific information is not available. 


\section{Acknowledgements}

The Grain Laboratory of the Plant Production Inspection Centre gave the considerable support for this study, by allowing the use of their sample archive and sample data. We are also indebted to the grain product company Melia $\mathrm{Oy}$ for their help in delivering surveillance samples. We are grateful to the personne? of the Ecology and Food chains Laboratory for their assistance in the sample treatment and analyses.

\section{References}

[1] Rajama J., Rantavaara A., Radioactivity in Finnish cereals from 1962 to 1980 (Institute of Radiation Protection, Helsinki, Finland, 1983).

[2] Studies on Environmental Radioactivity in Finland 1980. Annual Report. STL-A38 (Institution of Radiation Protection, Helsinki, 1982) pp. 51-64.

[3] Studies on Environmental Radioactivity in Finland 1981. Annual Report. STL-A40 (Institution of Radiation Protection, Helsinki, 1983) pp. 57-72.

[4] Studies on Environmental Radioactivity in Finland 1982. Annual Report. STL-A47 (Institution of Radiation Protection, Helsinki, 1984) pp. 53-69.

[5] Studies on Environmental Radioactivity in Finland 1983. Annual Report. STL-A48 (Helsinki: Institution of Radiation Protection, Helsinki, 1986) pp. 49-67.

[6] Studies on Environmental Radioactivity in Finland 1984-1985. Annual Report. STUK-A54 (Finnish Centre for Radiation and Nuclear Safety, Helsinki, 1987) pp. 59-89.

[7] Rantavaara A. and S. Haukka S., Radioactivity of milk, meat, cereals and other agricultural products in Finland after the Chemobyl accident in 1986. Supplement 3 to Annual Report STUK-A55. STUKA58, (Finnish Centre for Radiation and Nuclear Safety, Helsinki, 1987).

[8] Rantavaara A., Radioactivity of foodstuffs in Finland in 1987-1988. Supplement 4 to the Annual Reports STUK-A74 and STUK-A89. STUK-A78, (Finnish Centre for Radiation and Nuclear Safety, Helsinki, 1991).

[9] Arvela H., Markkanen M., Lemmelä H., Radiation Protection Dosimetry, Vol. 32, No. 3 (1990), pp. $177-184$.

[10] Kăhări J., Mäntylahti V., Rannikko M., Soil Fertility of Finnish Cultivated Soils in 1981-1985. (Viljavuuspalvelu Oy, Helsinki, 1987).

[11] Sinkko K., Computer analysis for gamma-ray spectra in sample measurements. Licenciate Thesis. (University of Helsinki, Department of Physics, Helsinki, 1981) (in Finnish).

[12] Klemola S. and Leppänen A., GAMMA-97 -Gamma-Ray Spectrum Analysis Program.

Documentation and User's Manual. (STUK, Helsinki, 1997).

[13] Bryant F.J., Morgan A., Spicer G.S., The determination of radiostrontium in biological materials, Report AERE-R 3030 (United Kingdom Atomic Energy Authority, Research GroupHarwell, 1959).

[14] Hewitt W.J., Bronislawa G. Determination of Radiostrontium in Milk Using an Extraction Chromatography Column. Radioactivity \& Radiochemistry Vol. 5, No. 3 (1994) pp. 8-16.

[15] Paasikallio A., Häkkinen U., Lakanen E., Ann. Agric. Fenn. 10 (1971) pp.125-130.

[16] Lakanen E., Paasikallio A., Ann. Agric. Fenn. 7 (1968) pp. 89-94.

[17] Lakanen E., A. Paasikallio, Ann. Agric. Fenn. 9 (1970) pp.133-138.

[18] Paasikallio A., Rantavaara A., Sippola J., The Science of the Total Environment 155 (1994) pp. 109 124. 